\title{
Efficacy of Probiotics in Irritable Bowel Syndrome-a Randomized, Double Blind Placebo-controlled Study
}

\author{
Md. Zahidur Rahman', Mohammad Shoaib Chowdhury², Mohammad Asadur Rahman ${ }^{2}$, Shohely Parveen ${ }^{3}$, \\ Rajib Barua ${ }^{2}$,Shamsuddin Mohammad Ishaque ${ }^{4}$, Dewan Saifuddin Ahmed ${ }^{4}$, A.S.M.A. Raihan ${ }^{5}$ \\ ${ }^{1}$ Assistant Professor, Department of Gastroenterology, ${ }^{2}$ Medical Officer, Department. of Gastroenterology, ${ }^{3}$ Medical Officer, Department of Paediat- \\ rics, ${ }^{4}$ Associate Professor, Department of Gastroenterology, 5 Professor and Chairman, Dept. of Gastroenterology, Bangabandhu Sheikh Mujib Medical \\ University ( BSMMU)
}

\begin{abstract}
:
Background :Gut flora have important trophic effects on intestinal epithelia and on immune structure and function. They also protect colonized host against invasion by alien microbes. Recent research suggests that an imbalance of the intestinal microbiota and a dysfunctional intestinal barrier might trigger irritable bowel syndrome (IBS). As probiotics have been reported to restore the intestinal microbiota and the gut barrier, the therapeutic potential of probiotics within IBS became of strong interest. Objectives:To assess the efficacy of probiotics in IBS. Methods :Patients of 15 to 60 years old and both sexes were included from the out patient department (OPD) of gastroenterology, Bangabandhu Sheikh Mujib Medical University (BSMMU). A validated IBS-QOL instrument consisted of 34 questions used to assess improvement of quality of life before and after treatment. A total of 65 diarrhoea predominant IBS patients were randomised to receive either probiotics(n-33) or placebo(n-32) twice daily for 6 weeks. Results: At the end of 6 weeks therapy, improvement in various symptoms(abdominal pain, stool frequency, consistency and flatulence) in probiotics group was statistically significant. Mean QOL score before treatment was 103 in probiotics group and 106 in placebo group. After 6 weeks of treatment mean QOL score was 82 in probiotics group and 102.58 in placebo group. No side effects of the therapeutic agents were observed in any patient during the trial. Conclusions :Probiotics effectively alleviates global IBS and improves IBS symptoms simultaneously with an improvement of quality of life.
\end{abstract}

Key words: Irritable bowel syndrome(IBS), Probiotics, Irritable bowel syndrome -Quality of life(IBS-QOL).

[BSMMU J 2013; 6 (1): 21-28]

\section{Introduction :}

Irritable bowel syndrome (IBS) is the most common functional gastrointestinal disorder in clinical particel. It is also one of the poorly understood chronic conditions in part because it is not a disease but a syndrome composed of a number of symptoms with similar manifestation 2,3. Several hypoththeses attempt to account for the pathophysiology of IBS, but the etiology still remains uncertain or obscure, perhaps multifactoral. Recent research has provided increasing support for the idea that disturbances of intestinal microbiota (in particular a significant reduction in the amount of intraluminal Bifidobacteria or Lacto-

Address of correspondence: Dr Md Zahidur Rahman, Assistant professor Dept. of Gastroenterology, Bangabandhu Sheikh Mijib Medical University ( BSMMU ). bacilli) occur in patients with IBS. An imbalanced micribiota may contribute to GI symptoms through altered colonic fermentation resulting in the increased formation of gas, an abnormal pattern of short chain fatty acids and motility or sensitivity disturbances of the intestinal tract.Evidence has now accumulated to suggest the efficacy of certain probiotics which may be capable of bringing about a significant reduction in pain, abdominal distension and flatulence, while increasing health-related quality of life in IBS4,5.

The prevalence of IBS has not been firmly established, but it has been estimated that IBS affected $14-24 \%$ of women and $5-15 \%$ of men in a western country6. The world wide prevalence is $10-20$ percent6. IBS is more 
in female in a rural community in Bangladesh ${ }^{7}$.

No specific diagnostic procedures identify IBS, because the underlying pathophysiology remains unknown. Thus, the diagnosis remains dependent on symptoms and exclusion of major organic diseases ${ }^{8,9}$. IBS has almost always been incurable and the approach therefore, can only be palliative. Many drugs have been advocated in treatment of IBS, for instance, spasmolytics, bulking and psychotropic agents, 5-HT receptor antagonists and probiotics.

Probiotics are supplements that are made up of live strains of good bacteria that are found normally in the body. There is growing awareness that the microflora make-up of the human body affects the overall health and risks for subsequent diseases. IBS symptoms are thought to come from the imbalance of the bacteria in the gut. A balance of the microflora to normal conditions might reduce symptoms in those who suffer from IBS. Probiotics promote health by its ability to improve the balance of good bacteria in the gut.Probiotics regulate fermentation of non-degradable dietary fiber and intraluminal mucoproteins, favors lactose digestion,modulate intraluminal gas production, reducing the bacteria that produce it (E. coli, Veillonella) and increasing the bacteria that do not (Lactobacilli, Bifidobacteria).Probiotics increase in trophic responses and regulate intestinal motility (fasting and postprandial) ${ }^{10}$.

Although probiotics are being widely used in Bangladesh for treating IBS patients for a long time, their efficacy has not been studied in well designed clinical trial. So, this prospective randomized clinical trial has been conducted in diarrhea predominant IBS patients, using probiotics and placebo in separate group of patients to see the short-term efficacy in relation to change of symptoms score in all groups of patients and to see the change of quality of life (QOL) score before and after treatment .

\section{Methods:}

This prospective randomized, double blind placebocontrolled study was conducted among the patients attending to gastroenterology OPD of BSMMU during the period from December 2010 to December 2011. Patients aged between 15 to 60 years, fulfilling the Rome II criteria for IBS diagnosis, having no red flags sign and having secondary education level so that they could fill-up questionnaire perfectly were included in the study. Pregnant and lactating mother and patients having concomitant severe illness were excluded from the study. Detailed history was taken and meticulous physical examination was done. Complete blood count, blood glucose, serum TSH, serum tissue transglutaminase (TTG) ,stool R/M/E , endoscopy of UGIT with distal duodenal biopsy,barium follow through of small intestine and colonoscopy was done in all patients to exclude any organic disease. All the patients were advised to exclude milk and milk products during the study period. Any patients having treatment for IBS were excluded from the study sample. Only diarrhea predominant patients were included. For the purposes of this study diarrhea was defined as patients self described passage of wet, soft stool more than 3 motions per day. A total of 72 patients were included in this study. Total number of Patients were divided into two groups randomly by lottery method. Each group consisted of 36 patients. One group treated with probiotics (Cap Probio, Square Herbal and Nutraceuticals Ltd containing Lactobacillus acidophilus 2billion, Lactobacillus bulgaricus 1 billion, Bifidobacterium bifidun 1 billion and Fructo- oligosaccharides $100 \mathrm{mg}$ ) twice daily and another group treated with placebo (components were lactulose, wheat ear, colloidal silicon dioxide, talc and magnesium stearate) twice daily for 6 weeks. Changes of symptoms and quality of life of patient were assessed by using a previously used validated IBS-QOL instrument11. Symptoms scoring system of IBS (table- 1) included four major symptomsabdominal pain, stool frequency, consistency and flatulence. Symptoms score was applied before starting the treatment as baseline and 2 weekly for 6 weeks. This scoring was done by doctor on the basis of 2 weekly interview. 
Table-I

Scoring system for weekly assessment of symptoms of IBS

\begin{tabular}{|c|c|c|c|c|c|}
\hline Symptoms & $\begin{array}{l}\text { None } \\
\text { ( } 0 \% \text { of time) }\end{array}$ & & $\begin{array}{l}\text { Occasional } \\
(0-25 \%) \text { of times }\end{array}$ & $\begin{array}{l}\text { Frequent } \\
\text { (25-50\% of }\end{array}$ & $\begin{array}{l}\text { Permanent } \\
>50 \% \text { of time }\end{array}$ \\
\hline \multirow[t]{2}{*}{ Abdominal pain } & pain scor & e & pain score & pain score & pain score \\
\hline & between $0-2$ & & between $3-4$ & between $\quad 5-7$ & between $8-10$ \\
\hline \multicolumn{6}{|c|}{ Altered stool frequency } \\
\hline$>3$ times /day & 0 & & 1 & 2 & 3 \\
\hline$<1$ times/day & 0 & & 1 & 2 & 3 \\
\hline \multicolumn{6}{|l|}{ Altered stool form } \\
\hline Hard & 0 & & 1 & 2 & 3 \\
\hline Soft & 0 & & 1 & 2 & 3 \\
\hline Flatulence & 0 & & 1 & 2 & 3 \\
\hline
\end{tabular}

If abdominal pain decreases to $25 \%$ of times in a week from baseline afer treatment(pain score decreases to less than 4), indicates significant improvement.

If stool frequency oceurs $>3$ times /day less than $25 \%$ of times from baseline per week, it indicates significant improvement.

If soft stool and flatulence occurs less than $25 \%$ of times from baseline per week, it indicates significant improvement.

QOL instrument were translated into Bengali and were given to each patients before treatment. Patient himself scored on IBS-QOL instrument. All data were recorded in a printed data sheet. Paired $\mathrm{T}$ test done to compare the symptom before and after treatment for probiotics and placebo group and Chi square test is applied to compare between probiotics and placebo group.

\section{Results:}

Among 72 patients following randomization, 36 patients (male 32, Female 4) were assigned to receive Cap Probio, 36 patients (male 30 , female 6 ) to receive placebo preparation. There were no statistically significant difference between the two group with respect to age and sex. Age ranges of the patients were 15 to 60 years. Mean age of probiotic group and placebo group were $27.3 \pm 5.28$ years and $30.49 \pm 8.68$ years respectively (Table-2).

Table -II

Baseline characteristic of the patients with IBS

\begin{tabular}{|c|c|c|}
\hline Parameters & $\begin{array}{l}\text { probiotic group } \\
(\mathrm{N}=36)\end{array}$ & $\begin{array}{l}\text { placebo Group } \\
\text { (N-36) }\end{array}$ \\
\hline Age & $27.32 \pm 5.28$ years & $30.49 \pm 8.68$ years \\
\hline \multicolumn{3}{|l|}{ Sex } \\
\hline Male & 32 & 30 \\
\hline Female & 4 & 6 \\
\hline
\end{tabular}

There were no significant differences in severity of symptoms between probiotic and placebo group at baseline. Total 7 patients were dropped out from this study, of which 3 were from probiotic group and 4 were from the placebo group due to unknown causes. Total 65 patients completed the trial. 
Among 33 patients in probiotic group, 30 patients suffered from a pain score between 5 and 10 points at baseline. At the end of this study, only 8 patients $(25.67 \%)$ had same level of pain, 22 patients (73.33\%) had marked improvement in pain score (less than 4) (Table-3). In the placebo group, 25 patients had a pain score between 5 and 10 points at the baseline. At the end of the study,11 patients $(44 \%)$ had same level of pain, improvement observed in 14

Table-III

Abdominal pain

\begin{tabular}{|c|c|c|c|c|c|c|c|c|}
\hline \multirow[t]{2}{*}{ Symptom score } & \multicolumn{2}{|c|}{ Before treat. } & \multicolumn{2}{|c|}{ After 6 wk } & \multicolumn{2}{|c|}{$\%$ of patients of improvement } & \multicolumn{2}{|c|}{ P Value } \\
\hline & $\begin{array}{l}\text { Probiotic } \\
\text { Group } \\
(n=33)\end{array}$ & $\begin{array}{l}\text { Placebo } \\
\text { group } \\
(\mathrm{n}-32)\end{array}$ & $\begin{array}{l}\text { Probiotic } \\
\text { Group }\end{array}$ & $\begin{array}{l}\text { Placebo } \\
\text { group }\end{array}$ & $\begin{array}{l}\text { Probiotic } \\
\text { Group }\end{array}$ & Placebo group & $\begin{array}{l}\text { Probiotic } \\
\text { Group }\end{array}$ & $\begin{array}{l}\text { Placebo } \\
\text { group }\end{array}$ \\
\hline $\begin{array}{l}\text { None }(0) \\
\text { Pain Score between 0-2 }\end{array}$ & 1 & 1 & 10 & 3 & & & & \\
\hline $\begin{array}{l}\text { Occasional (1) } \\
\text { Pain Score between 3-4 }\end{array}$ & 2 & 6 & 15 & 18 & 73.33 & 56 & $\begin{array}{l}<0.05 \\
<0.1\end{array}$ & \\
\hline $\begin{array}{l}\text { Frequent (2) } \\
\text { Pain Score between 5-7 }\end{array}$ & 10 & 13 & 7 & 10 & & & & \\
\hline $\begin{array}{l}\text { Permanent ( } 3 \text { ) } \\
\text { Pain Score between 8-10 }\end{array}$ & 20 & 12 & 1 & 1 & & & & \\
\hline
\end{tabular}

Of the patients receiving probiotic, 30 patients had stool frequency more than 3 times/day in more that $25 \%$ of time at baseline. After 6 weeks, only 7 patients $(23.34 \%)$ had the same frequency of stool motion,23 patients $(76.34 \%)$ had marked improvement (Table-4). In the placebo group, 29 patients had stool frequency more than 3 times/day in more than $25 \%$ of time at baseline. After 6 weeks , 15 patients $(51.72 \%)$ had same frequency of stool motion, patients $(56 \%)$ (Table-3). Improvement of pain score after treatment in probiotic group was statistically significant ( $p$ value $<0.05$ ) but improvement of pain score after treatment in placebo group was not statistically significant ( $p$ value $<0.1$ ). Difference of improvement between probiotic and placebo groups was also statistically significant $(\mathrm{p}<0.05)$ improvement observed in 14 patients $(48.28 \%)($ (Table-4). Imrovement in patients in respect to bowel frequency in probiotic groups was statistically significant ( $<<0,05$ ) in respect to baseline, but Imrovement in patients in respect to bowel frequency in placebo group was not statistically significant $(\mathrm{p}<0.5)$. The difference of improvement between probiotic and placebo groups is statistically significant $(\mathrm{p}<0.05)$.

Table-IV

Altered stool frequency $>3$ times/day:

\begin{tabular}{|c|c|c|c|c|c|c|c|c|}
\hline \multirow[t]{2}{*}{ Symptom score } & \multicolumn{2}{|c|}{ Before treat. } & \multicolumn{2}{|c|}{ After 6 wk } & \multicolumn{2}{|c|}{$\%$ of patients of improvement } & \multicolumn{2}{|c|}{ PValue } \\
\hline & $\begin{array}{l}\text { Probiotic } \\
\text { Group } \\
(\mathrm{n}=33)\end{array}$ & $\begin{array}{l}\text { Placebo } \\
\text { group } \\
(\mathrm{n}-32)\end{array}$ & $\begin{array}{l}\text { Probiotic } \\
\text { Group }\end{array}$ & $\begin{array}{l}\text { Placebo } \\
\text { group }\end{array}$ & $\begin{array}{l}\text { Probiotic } \\
\text { Group }\end{array}$ & Placebo group & $\begin{array}{l}\text { Probiotic } \\
\text { Group }\end{array}$ & $\begin{array}{l}\text { Placebo } \\
\text { group }\end{array}$ \\
\hline $\begin{array}{l}\text { None }(0) \\
0 \% \text { of time }\end{array}$ & 0 & 0 & 10 & 3 & & & & \\
\hline $\begin{array}{l}\text { Occasional (1) } \\
0-25 \% \text { of time }\end{array}$ & 3 & 3 & 16 & 14 & 76.66 & 48.28 & $\begin{array}{l}<0.05 \\
<0.5\end{array}$ & \\
\hline $\begin{array}{l}\text { Frequent (2) } \\
25-50 \% \text { of time }\end{array}$ & 10 & 5 & 6 & 10 & & & & \\
\hline $\begin{array}{l}\text { Permanent (3) } \\
>50 \% \text { of time }\end{array}$ & 20 & 24 & 1 & 5 & & & & \\
\hline
\end{tabular}

Among the patients receiving probiotic, 30 patients had soft stool more than $25 \%$ of time at the baseline. After 6 weeks ,only $8(26.67 \%)$ had this same level of consistency, 22 patients $(73.33 \%)$ had marked improvement (Table-5). Among the placebo group 30 patients had soft stool in more than $25 \%$ of time at the baseline. After 6 weeks, 24 patients $(80 \%)$ had the same level of consistency,improvement observed in only 6 patients $(20 \%)$ ( (Table-5). Improvement in probiotic group in respect to soft stool was statistically significant $(\mathrm{p}<0.05)$ in respect to baseline. But Improvement in placebo group in respect to soft stool was not statistically significant $(p<0.5)$. The difference of improvement between probiotic and placebo groups is also statistically significant $(\mathrm{p}<0.05)$. 
Table-V

\begin{tabular}{|c|c|c|c|c|c|c|c|c|}
\hline \multirow{3}{*}{ Symptom score } & \multicolumn{6}{|c|}{ Soft stool } & \multirow{2}{*}{\multicolumn{2}{|c|}{ PValue }} \\
\hline & \multicolumn{2}{|c|}{ Before treat. } & \multicolumn{2}{|c|}{ After 6 wk } & \multicolumn{2}{|c|}{$\%$ of patients of improvement } & & \\
\hline & $\begin{array}{l}\text { Probiotic } \\
\text { Group } \\
(n=33)\end{array}$ & $\begin{array}{l}\text { Placebo } \\
\text { group } \\
(\mathrm{n}-32)\end{array}$ & $\begin{array}{l}\text { Probiotic } \\
\text { Group }\end{array}$ & $\begin{array}{l}\text { Placebo } \\
\text { group }\end{array}$ & $\begin{array}{l}\text { Probiotic } \\
\text { Group }\end{array}$ & Placebo group & $\begin{array}{l}\text { Probiotic } \\
\text { Group }\end{array}$ & $\begin{array}{l}\text { Placebo } \\
\text { group }\end{array}$ \\
\hline $\begin{array}{l}\text { None }(0) \\
0 \% \text { of time }\end{array}$ & 0 & 0 & 10 & 2 & & & & \\
\hline $\begin{array}{l}\text { Occasional (1) } \\
0-25 \% \text { of time }\end{array}$ & 3 & 2 & 15 & 6 & 73.33 & 20 & $\begin{array}{l}<0.05 \\
<0.5\end{array}$ & \\
\hline $\begin{array}{l}\text { Frequent (2) } \\
25-50 \% \text { of time }\end{array}$ & 12 & 9 & 7 & 17 & & & & \\
\hline $\begin{array}{l}\text { Permanent }(3) \\
>50 \% \text { of time }\end{array}$ & 18 & 21 & 1 & 7 & & & & \\
\hline
\end{tabular}

Among the patients receiving probiotic , 30 patients had flatulence more than $25 \%$ of time at baseline. After 6 weeks, 7 patients $(23.34 \%)$ had the same level of flatulence, 23 patients $(76.66 \%)$ had marked improvement (Table-6). In the placebo group, 26 patients had flatulence more than $25 \%$ of time at baseline. After 6 weeks ,24 patients $(92.30 \%)$ had the same level of flatulence,improvement observed in only 2 patients $(7.7 \%)$ (Table-6). Improvement in patients in respect to flatulence in probiotic group was statistically significant $(\mathrm{p}<0.05)$ in respect to baseline. But improvement in placebo group was not statistically significant $(\mathrm{P}<0.5)$. The difference of improvement between probiotic and placebo groups is also statistically significant ( $\mathrm{p}$ $<0.02$ ).

Table-VI

Flatulence

\begin{tabular}{|c|c|c|c|c|c|c|c|c|c|}
\hline \multirow[t]{2}{*}{ Symptom score } & & \multicolumn{2}{|c|}{ Before treat. } & \multicolumn{2}{|c|}{ After $6 \mathrm{wk}$} & \multicolumn{2}{|c|}{$\%$ of patients of improvement } & \multicolumn{2}{|c|}{ P Value } \\
\hline & ; & $\begin{array}{l}\text { Probiotic } \\
\text { Group } \\
(\mathrm{n}=33)\end{array}$ & $\begin{array}{l}\text { Placebo } \\
\text { group } \\
(\mathrm{n}-32)\end{array}$ & $\begin{array}{l}\text { Probiotic } \\
\text { Group }\end{array}$ & $\begin{array}{l}\text { Placebo } \\
\text { group }\end{array}$ & $\begin{array}{l}\text { Probiotic } \\
\text { Group }\end{array}$ & Placebo group & $\begin{array}{l}\text { Probiotic } \\
\text { Group }\end{array}$ & $\begin{array}{l}\text { Placebo } \\
\text { group }\end{array}$ \\
\hline $\begin{array}{l}\text { None }(0) \\
0 \% \text { of time }\end{array}$ & & 0 & 0 & 11 & 2 & & & & \\
\hline $\begin{array}{l}\text { Occasional (1) } \\
0-25 \% \text { of time }\end{array}$ & & 3 & 6 & 15 & 6 & 76.66 & 7.70 & $\begin{array}{l}<0.05 \\
<0.5\end{array}$ & \\
\hline $\begin{array}{l}\text { Frequent ( } 2 \text { ) } \\
25-50 \% \text { of time }\end{array}$ & - & 14 & 15 & 5 & 18 & & & & \\
\hline $\begin{array}{l}\text { Permanent ( } 3 \text { ) } \\
>50 \% \text { of time }\end{array}$ & & 16 & 11 & 2 & 6 & & & & \\
\hline
\end{tabular}

A validated IBS-QOL has been used which consist of 34 questions. Each had potential score of 1 to 5 points. So minimum scor is 34 and maximum score is 170 . Patient himself/herself scored on QOL instrument before and after treatment. In probiotic group score before treatment was 103.64 and in placebo group mean score was 106.36. After treatment, mean score of probiotic group was 82.80 and in placebo group was 102.58 (Table-7). The improve- ment in QOL score in probiotic group after treatment was statistically significant ( $p$ value $<0.05$ ). But The improvement in QOL score in placebo group after treatment was not statistically significant ( $p$ value $<0.138$ ). Difference in improvement between probiotics and placebo group at the end of treatment was also statistically significant $(\mathrm{P}$ value $<0.05)$ (Table- 8 ).

Table-VII

$I B S-Q O L$ mean score before and after treatment

\begin{tabular}{llll}
\hline & Before treatment & After treatment & P Value \\
\hline probiotic group $(\mathrm{n}=62)$ & 103.64 & 82.80 & $(\mathrm{P}<0.05)$ \\
Placebo group $(\mathrm{n}=60)$ & 106.36 & 102.58 & $(\mathrm{P}<0.138)$ \\
\hline
\end{tabular}


Table-VIII

IBS-QOL score between probiotic and placebo group after 6 weeks of treatment

\begin{tabular}{|c|c|c|c|}
\hline & probiotic group & placebo group & P Value \\
\hline QOL Score & 82.80 & 102.58 & $<0.05$ \\
\hline
\end{tabular}

\section{Discussion :}

The emerging epidemiologic, physiological, and clinical data over the past few years have provided evidence that the intestinal microbiota play an important role in maintaining normal gastrointestinal (GI) function ${ }^{12}$. It has been stated that the imbalance of the microbiotic composition may lead to a different fermentation pattern, especially with increased hydrogen production resulting in bloating ${ }^{13}$. Additionally, gut mucosal barrier disruption has been proven to be associated with bacterial translocation and inflammatory conditions ${ }^{14,15}$. Furthermore, recent clinical data indicate that manipulation of the intestinal microbiota by probiotics may be effective in alleviating symptoms of IBS $^{16}$.

Probiotics reportedly bind to small and large bowel epithelium and produce substances with antibiotic properties that may inhibit attachment and invasion by pathogenic organisms. Probiotics may also modulate gastrointestinal luminal immunity by changing the cytokine and cellular milieu from a proinflammatory to anti-inflammatory state . They may also convert undigested carbohydrates into short chain fatty acids, which act as nutrients for colonocytes and alter gut motility. Therefore, it has been theorized that probiotics may lead to symptomatic improvements in patients with IBS $^{16}$.

Taking into consideration the pathophysiology of IBS and the role of adherence of probiotics regarding the restoration of the intestinal microbiota as well as of the gut barrier,probiotics might be effective for treatment of IBS.As the conventional medical treatment of IBS is unsatisfactory, we have evaluated the efficacy of probiotics. This randomized,double blind, placebo-controlled study indicates that probiotics have beneficial effects in the treatment of IBS. Primary end points of this study were global relief of GI symptoms and satisfaction with treatment.Secondary end points were change in symptoms severity, well -being and quality of life. Improvement of symptoms were assessed weekly and finally at 6 weeks.In this study, probiotics significantly improved global IBS as well as its related symptoms such as abdominal pain,stool frequency,consistency and flatulence compared with placebo.Moreever, probiotics also significantly improved quality of life.

Studies in IBS patients have attempted to target changes in intestinal microflora with different therapeutic approaches, including the use of prebiotics, probiotics, synbiotics, and nonabsorbable and systemic antibiotics ${ }^{17}$. Single strains of Lactobacilli or Bifidobacteria have been used in the majority of probiotic trials ${ }^{18-26}$. Two studies used a composite probiotic (VSL $\# 3$ ), containing multiple strains of Bifidobacteria and Lactobacilli, and 1 strain of Streptococci. ${ }^{27-28}$ Another recent study used a multispecies probiotic including Lactobacilli rhamnosus GG, L. rhamnosus Lc705, Propionobacterium freudenreichii spp., Propionobacterium shermanii JS, Bifidobacterium breve Bb99. Similar to our findings, the results obtained in these studies suggest some beneficial effect of probiotics over placebo in the relief of IBS symptoms ${ }^{24-29}$.

A recent well-designed study, in which Bifidobacterium infantis 35624 was used, demonstrated also a significant improvement of global assessment with a $20 \%$ gain over placebo $^{25}$. There is also initial evidence that Bifidobacterium animalis DN-173 010 could improve health-related quality of life in IBS patients ${ }^{26}$ which is similar to the findings of our study. It is interesting to note that some studies have also evaluated the impact of probiotics on certain pathophysiologic features of IBS. In their study, O'Mahony et al have shown that B. infantis 35624 was able to reduce systemic proinflammatory cytokine profile, thus providing a possible mechanism through which this probiotic could be beneficial in $\mathrm{IBS}^{24}$. Kim et al have demonstrated that VSL $\# 3$ delays colonic transit in IBS patients with bloating ${ }^{28}$. Interestingly, there is also initial evidence indicating the beneficial effect of a multi- 
initial evidence indicating the beneficial effect of a multispecies probiotic formulation on certain metabolic aspects of intestinal microbiota in IBS patients ${ }^{30}$. Recently, Brenner et al. published a systematic review of randomized controlled trials(RCTs) aimed at the evaluation of the efficacy, safety and tolerability of probiotics in the treatment of IBS.A total of 16 RCTs were included in the analysis and showed improvement of IBS symptoms ${ }^{15}$.Together with these studies,our study results further support the hypothesis that the beneficial effects of manipulation of the intestinal microbiota in patients with IBS have effects on global relief of GI symptoms.

In the present study, it was found that probiotics are effective in relieving various symptoms of IBS. Significant improvements in abdominal pain occurred in patients taking probiotics $(73.33 \%)$ compared to placebo $(56 \%)$. Significant improvements in stool frequency, consistency and flatulence were also observed in patients taking probiotics $(76.66,73.33,76.66 \%$ respectively ) compare to placebo( $48.28,20,7.70 \%$ respectively ).IBS-QOL instrument was used as a parameter of improvement of this trial. It showed that probiotics also significantly improve the QOL. The improvement of patients taking probiotics is also significantly different from the placebo group. Tolerance of the drug was excellent, and no difference in adverse events was noted between probiotics and placebo group. So probiotics generally regarded as safe.

There were several limitations of this study .Patients were selected from a tertiary health care center only and number of patients were small. Larger scale studies are needed for further evaluation of the efficacy of probiotics for the IBS patients seen in the primary and secondary health care centers. Also we follow the patients only for 6 weeks, so extent of the benefit were not evaluated. In this study we use probiotics containing 3 organism- Lactobacillus acidophilus, Lactobacillus bulgaricus and Bifidobacterium bifidun. So further study can be done with probiotics containing multispecies.

\section{Conclusion:}

This study provides additional support to the hypothesis that manipulation of the intestinal microbiota may be beneficial in patients with IBS. Our findings suggest that the combination of probiotic bacteria used in this study may be helpful in alleviating symptoms in patients with functional GI disorders. The clinical benefit of this intervention needs further investigation.

\section{References :}

1. Thompson WG, Gred F, Drossman DA, Heaton KW, Mazzacea G. Functional bowel disorder and functional abdominal pain. Gastroenterol 1992;5:75-91.

2. Tally NJ: Functional gastrointestinal disorders. In: Friedman SL, McQuaid KR, Grendell JH, editors. Current diagnosis and treatment in Gastroenterology.Second edition.New York: McGraw-Hill companies; 2003.p.97-107.

3. Snape WJ: Irritable bowel syndrome. In: Haubrich WS, Schaffer F. editors. Bockus gastroenterology. 5th ed. Philadelphia : WB saunders company; 1995.p.1619-35

4. M.Bixquet Jimenez.Treatment of irritable bowel syndrome with probiotics. An etiopathogenetic approach at last? Rev Esp Dig 2009:101:553-64.

5. Thompson WG. Irritable bowel syndrome: Pathogenesis and Management. Lancet 1993; 341:1569-72.

6. Drossman DA, Liz Andruzi E. US Househholder survey of functional GI disorder, prevalence, socio-demography, and health impact. Dig Dis Sci 1993; 38:1569-80.

7. Masud MA, Hasan M, Azad Khan AK. Irritable bowel syndrome in a rural community in Bangladesh.Prevalance, symptom pattern, and health care seeking behavior. Am J Gastroenterol 2001:96:1547-52.

8. LynnBR, Friedman SL. Irritable bowel syndrome. N Engl J Med 1993;329:1910-45.

9. Thompson WG, Dotevall G, Drossman DA, Binder V, Kreiner S, Peters TJ, et al. Irritable bowel syndrome: Guideline for the diagnosis. Gastroenterol 1989;2:92-5.

10. Douglas LC, Scanders ME. Probiotics and prebiotics in dietetics practice. J AM Diet Assoc. 2008;108:510-21.

11. Drossman DA, Patrick DL, Whithead WE, Toner BB, Diamarit $\mathrm{NE}, \mathrm{Hu} \mathrm{Y}$, et al. Further validation of the IBS-QOL. A disease specific quality of life questionnaire. Am J gastroentol 2000;95:999-1007.

12. Saito YA, Schoenfeld P, Locke GR. The epidemiology of irritable bowel syndrome in North America: a systematic review. Am J Gastroenterol 2002;97:1910-15.

13. Longstreth GF, Thompson WG, Chey WD, Houghton LA, Mearin F, Spiller RG, et al. Functional bowel disorders. In: Drossman DA, Corazziari E, Delvaux M, et al. editors. Rome III: The Functional Gastrointestinal Disorders. 3rd edition. McLean (VA): Degnon Associates; 2006; P.487-555.

14. Ringel Y, Carroll I. Alternations of Intestinal Microbiota and Functional Bowel Symptoms: in "Gastrointestinal Motility and Neurogastroenterology". Gastrointest Endosc Clin N Am 2009;19:141-150

15. Brenner DM, Moeller MJ, Chey WD,Schoenfeld PS. The utility of probiotics in the treatment of irritable bowel syndrome: a systematic review. Am J Gastroenterol 2009;104:1033-49. 
16. Moayyedi P, Ford AC, Talley NJ, Cremonini F, Fox-Orentein AE, Brandt LJ, et al. The efficacy of probiotics in the therapy of irritable bowel syndrome: a systematic review. Gut 2010;59:325-32.

17. Barbara G, Stanghellini V, Brandi G, Cremon C, Nardo GD, Giorgio $\mathrm{RD}$, et al. Interactions between commensal bacteria and gut sensorimotor function in health and disease. Am $\mathrm{J}$ Gastroenterol 2005; 100:2560-68.

18. Halpern GM, Prindiville T, Blankenburg M, Read NW, Brown C, Rao SS,et al. Treatment of irritable bowel syndrome with Lacteol Fort: a randomized, doubleblind, cross-over trial. Am J Gastroenterol 1996;91:1579-85.

19. Nobaek S, Johansson ML, Molin G,Ahrne S, Jeppsson B. Alteration of intestinal microflora is associated with reduction in abdominal bloating and pain in patients with irritable bowel syndrome. Am J Gastroenterol 2000;95:1231-38.

20. O'Sullivan MA, O'Morain CA. Bacterial supplementation in the irritable bowel syndrome. A randomised double blind placebocontrolled crossover study. Dig Liver Dis 2000;32:294-301.

21. Niedzielin K, Kordecki H, Birkenfeld B. A controlled, double-blind, randomized study on the efficacy of Lactobacillus plantarum $299 \mathrm{~V}$ in patients with irritable bowel syndrome. Eur J Gastroenterol Hepatol 2001;13:1143-47.

22. Sen S, Mullan MM, Parker TJ,Woolner JT, Tarr SA, Hunter JO. Effect of Lactobacillus plantarum $299 \mathrm{v}$ on colonic fermentation and symptoms of irritable bowel syndrome. Dig Dis Sci 2002;47:261520.

23. Niv E, Naftali T, Hallak R, Vaismon N. The efficacy of Lactobacillus reuteri ATCC 55730 in the treatment of patients with irritable bowel syndrome - a double blind, placebo-controlled, randomized study. Clin Nutr 2005;24:925-31.
24. O'Mahony L, McCarthy J, Kelly P,Hurley G, Luo F, Chen K, et al. Lactobacillus and Bifidobacterium in irritable bowel syndrome: symptom responses and relationship to cytokine profiles. Gastroenterology 2005;128: 541-51.

25. Whorwell PJ, Altringer L, Morel J, Bond Y, Charbonnean D, O' Mahony L, et al. Efficacy of an encapsulated probiotic Bifidobacterium infantis 35624 in women with irritable bowel syndrome. Am J Gastroenterol 2006;101:1581-90.

26. Guyonnet D, Chassany O, Ducrotte P, Picard C, Mouret M, Mercier $\mathrm{CH}$,et al. Effect of a fermented milk containing Bifidobacterium animalis DN-173 010 on the healthrelated quality of life and symptoms in irritable bowel syndrome in adults in primary care: a multicentre, randomized, double-blind, controlled trial. Aliment Pharmacol Ther 2007;26:475-86.

27. Kim HJ, Camilleri M, McKinzie S,Lempke MB, Burton DD, Baxter $\mathrm{K}$, et al. A randomized controlled trial of a probiotic, VSL $\# 3$, on gut transit and symptoms in diarrhoea-predominant irritable bowel syndrome. Aliment Pharmacol Ther 2003;17:895904.

28. Kim HJ, Vazquez Roque MI, Camilleri M, Stephens D, Burton DD, Thomforde GM, et al. A randomized controlled trial of a probiotic combination VSL \# 3 and placebo in irritable bowel syndrome with bloating. Neurogastroenterol Motil 2005;17:687-96.

29. Kajander K, Hatakka K, Poussa T,Farkkila M, Korpela R. A probiotic mixture alleviates symptoms in irritable bowel syndrome patients: a controlled 6-month intervention. Aliment Pharmacol Ther $2005 ; 22: 387-94$.

30. Kajander K, Krogius-Kurikka L, Rinttila T,Karjaleinen H, Palva A, korpela R, et al. Effects of multispecies probiotic supplementation on intestinal microbiota in irritable bowel syndrome. Aliment Pharmacol Ther 2007;26: 463-73. 